\title{
"To Sacrifice One's Intellect Is More Demonic than Divine": American Literature and Politics in Left Behind: A Novel of the Earth's Last Days
}

\section{Peter Swirski}

\section{OpenEdition}

\section{Journals}

Electronic version

URL: https://journals.openedition.org/ejas/10342

DOI: $10.4000 /$ ejas. 10342

ISSN: 1991-9336

Publisher

European Association for American Studies

Electronic reference

Peter Swirski, "'To Sacrifice One's Intellect Is More Demonic than Divine”: American Literature and Politics in Left Behind: A Novel of the Earth's Last Days", European journal of American studies [Online] 9-2 | 2014, document 2, Online since 26 September 2014, connection on 08 July 2021. URL: http:// journals.openedition.org/ejas/10342 ; DOI: https://doi.org/10.4000/ejas.10342

This text was automatically generated on 8 July 2021.

Creative Commons License 


\title{
“To Sacrifice One's Intellect Is More Demonic than Divine": American Literature and Politics in Left Behind: A Novel of the Earth's Last Days
}

\author{
Peter Swirski
}

\section{Introduction}

1 In 1995 two born-again evangelists sat down to pen what would turn out to be a phenomenally lucrative franchise. On paper, they were an odd couple behind a multiplatinum bestseller that from 1999 on would top The New York Times charts with each new instalment. One of them would never write a word of it. The other would ultimately dash off more than six thousand pages of earnest prose. Together they would become avatars of not trying to be taken seriously by literary critics, but being taken very seriously by the bankers.

2 Jerry B. Jenkins, the actual writer but only the second name on the cover, is the author of more than a hundred and fifty books, including several bestselling sports biographies and the nationally syndicated comic strip Gil Thorp. He is also a former president for publishing at the Moody Bible Institute of Chicago which runs the Moody Press, the port of call for biblical prophecy writers. Of late he has also cofounded the Christian Writers Guild which helps born-again novelists with marketing and writing in the same meat-and-potatoes style that drives Left Behind and the entire Left Behind Series (LBS).

3 Tim LaHaye, the prime mover behind the series, is himself the author of a long line of publications on Bible prophecy. Characteristically, in parallel to the LBS he launched the PreTrib Research Center dedicated to promoting the dispensationalist interpretation of the Book of Revelation. Back in 1979 he helped persuade Jerry Falwell to found the Moral Majority and joined its board of directors. In the 1980s, forsaking 
the pulpit to make room for writing and politics, he locked arms not only with Reaganera Republicans but also with the ultra-conservative John Birch Society whose agenda, from vilifying the UN to promoting an evangelical interpretation of the Constitution, gets a sympathetic airing throughout the LBS. ${ }^{i}$

4 LaHaye also got involved in presidential politics as a co-chairman of Jack Kemp's 1988 campaign, only to be kicked off in the first week when his inflammatory antiCatholicism became a public liability. In 2000 he played a major role in rallying the religious right to vote for George W. Bush, and in 2007 publicly threw his weight behind Mike Huckabee in the Republican primaries. The would-be president returned the favor by endorsing Left Behind and its sequels as a "compelling story written for nontheologians." ${ }^{\text {ii }}$

5 By then the entire series was winding down after fifteen years of success, with Left Behind nominated for Novel of the Year by the Evangelical Christian Publishers Association, LaHaye and Jenkins making the cover of Time (July 2002) and then Newsweek (May 2004), and sales receipts proving Matthew's error when he preached that ye cannot both serve God and mammon. In short, a mammoth triumph for a story that refurbishes the old and the New Testaments by cutting and pasting contemporary events into the dispensationalist catechism-"Nostradamus rewritten by Jeffrey Archer" in the wry summary of the London Times (Morrison 2-3).

6 Dispensationalism itself, an evangelical denomination with roots in the late 1820s Plymouth Brethren Movement, emigrated from the British Isles to America in the 1860s via the agency of an Anglican dissenter and itinerant preacher, John Nelson Darby. The centerpiece of his theology was the division of religious history into seven periods, or dispensations. In the beginning, preached Darby, was the Dispensation of Innocence (Adam and Eve in the garden east of Eden) succeeded by the Dispensation of Conscience (after the forbidden fruit). It was followed, in turn, by the Dispensation of Human Government (after God gave Noah the basic laws), of Promise (after the covenant with Abraham), of Law (after Mosaic laws on Mount Sinai), and of Grace or Church (after Jesus' resurrection). ${ }^{\text {iii }}$

7 The millennium-long kingdom to be established by Christ after the Second Coming is called the Dispensation of the Millennium. It will be inaugurated by the Rapture, during which all born-again Christians will be beamed up to heaven, and followed by the Tribulation during which Earth will be scourged by plagues and calamities of apocalyptic proportions. The holy war between God and Satan will wipe out most of humankind before the glorious return of Jesus, who will smite the Antichrist on the plain of Armageddon. He will then establish a thousand-year kingdom, albeit not on Earth, which will itself be annihilated, but on a planet identical to ours miraculously created in its place.

8 All that, including the pogrom of several billion souls: atheists, Catholics, Muslims, Buddhists, Hindus, Jews, and others who do not subscribe to the dispensationalist creed, is part of God's master plan to bring all to the true faith. For Darby, this theodicy was not a problem: his divine omelet clearly called for the breaking of a few billion eggs. The fact that God's retribution might rain indiscriminately on all people on Earth, born-again or not, was more disconcerting. In the end, Darby decided that, rather than suffer the equivalent of Amalric's 'Kill them all, for the Lord knows them that are His', true Christians would be spirited up to heaven just before the reign of terror began. Bailed out by the Rapture, they could then safely look down on God's carnage of those 
left behind. As to who qualifies as a true Christian, Darby's teachings were no different from that of the Calvinists, the Puritans, and the Separatists: nobody knows except the Lord.

9 Darby's uncompromising stance programmatically distanced him from institutionalized churches like the Roman Catholic which guarantee salvation to all who embrace it, and which historically allowed the wealthy to buy indulgences, pardons, benefices, dispensations, and other forms of simony. In contrast, in the bornagain order there would be no cutting corners. No church membership or pious works could put you among the regenerate. Only unquestioning obeisance to the doctrine as elucidated by the doctrinal elders would do. Darby's doctrinal platform was rooted in his interpretation of I Thessalonians 4:16-17:

16 For the Lord himself shall descend from heaven with a shout, with the voice of the archangel, and with the trump of God: and the dead in Christ shall rise first:

17 Then we which are alive and remain shall be caught up together with them in the clouds, to meet the Lord in the air: and so shall we ever be with the Lord.iv

Although his reified evangelicalism was ignored by other Christian denominations, his disciples spared no efforts to popularize its bright side, insofar as the Rapture exempted prospective converts from the hell on earth that was to befall unregenerate humankind. In 1909 their efforts received a major boost with the Oxford University Press publication of the Scofield Reference Bible by an apostle of Darby's, Cyrus I. Scofield.

11 Forging the illusion that these wildly eclectic texts all point to the dispensationalist creed, Scofield cross-referenced the entire old and New Testament, printing his glosses directly under the scriptures and in exactly the same font. ${ }^{v}$ Despite his exegeses being superimposed on the biblical verses-or perhaps because of it-the book became a big hit with fundamentalists (the revised 1966 edition is still in use). Institutionalized in the born-again Bible schools founded across America in the early twentieth century, it sold in excess of twenty million copies, paving the way for Left Behind and its version of Apocalypse Now.

\section{Deus ex Machina}

12 Left Behind, the first and most important novel in the series, opens onboard a transatlantic flight during which some passengers suddenly disappear from their seats, leaving nothing but bundles of clothing behind. Routed back to Chicago, the jetliner lands on the last open runway in the midst of pandemonium. Air-traffic controllers, dispatchers, motormen, drivers, surgeons were raptured while on duty, leaving a blaze of collateral death and chaos in their wake.

13 Against the terrors of the ensuing Tribulation, the book and the series follow a core group of characters: Rayford Steele, senior airline pilot from the opening pages, his spirited daughter Chloe, and her eventual husband, ace journalist "Buck" Williams. By the end of the first book all three become steadfast converts to dispensationalism. Tsion Ben-Judah, a Jewish rabbi who converts later in the series, becomes the theological spokesman for the group and for their real-life creators. Together with Pastor Barnes they form the so-called Tribulation Force which, over eleven sequels and four prequels, will evangelize the infidels and combat the Antichrist, Nicolae Carpathia, as he rises from obscurity to become the President of Romania, Secretary-General of the United Nations, and finally world dictator. Seven years and several billion corpses 
later, the Left Behind Series culminates in the glorious appearing of Christ at Armageddon where Carpathia and the forces of evil get slain exactly as prophesied by Scofield. The end.

14 If all this Bible-meets-Tom-Clancy soap opera sounds vaguely familiar, it is because once you have read one dispensationalist tract disguised as a novel, you have read them all. Even the locations (the United Nations, Petra, Babylon, Armageddon) are recycled from the stock of previous paper apocalypses, as are the Antichrist's campaigns for One-World Government, One-World Currency, and One-World Religion, together with their political insinuations: the EU, the World Bank, and the ecumenical movement are minions of Satan. Still, returns to familiar faces and places can be a source of aesthetic pleasure and emotional gratification, as corroborated by die-hard fans of genre cycles like Ed McBain's $87^{\text {th }}$ Precinct or television soaps like The West Wing. And genre and soap formulas come thick and fast right from page one of Left Behind.

15 The scenes of panic aboard the airliner hail straight from Alex Hailey's Flight into Danger and the bedlam on the ground from his other disaster thriller Airport. ${ }^{\text {vi }}$ Brushes with death, including a car bombing which rains a leg and part of a torso on the sidewalk, are all in a day's work for the born-again action hero Buck. Like all handsome, loaded, lone-wolf investigative reporters he packs his MacGyver ingenuity next to his false passport. Like them, he also operates in a comic-book fairyland. Tossing the passport and ID at the site of the bombing, Buck feels confident that the police would now conclude that he was one of the casualties (Left Behind 185). Evidently Jerry B. Jenkins has never heard of forensic odontology or DNA. ${ }^{\text {vii }}$

16 On another level, the series also styles itself as an extended self-help book and a vade mecum for the millennial Everyman. Rayford Steele may be yet another generic action hero-his name clearly rings up 1980s TV and Remington Steele-but his quest for salvation becomes a handbook of instructions for every would-be spiritual pilgrim. "So how do we become true Christians?" demands Steele. "I'm going to walk you through that," replies Pastor Barnes, "and I'm going to send you home with the tape" (200). viii

17 The sequels to Left Behind pump up the bloodshed over global theatres of war, deploying the obligatory military hardware, battle tactics, weapons specs, and aide-decamp mindset of a techno-thriller. The LBS also attempts to fashion itself into a geopolitical exposé. Buck penetrates the periphery of a Bilderberg-like cabal of politicians and high financiers who use their global leverage to elevate Carpathia to the status of world dictator. The Antichrist's acclamation as President of Romania is but the first in the succession of bloodless coups d'état, politically as surreal as "a freshman congressman becoming president of the United States in an off-election year, no vote, president steps down, and everybody's happy" (138).

18 Generic plotline, stock characters, potboiler formulas, and fairy tale miracles-at every turn Left Behind demands a suspension of disbelief. So does, of course, the credo quia absurdum est of the premillennialist belief system. Ironically, this literal and figurative affirmation of the power of fiction to imagine an alternative world and to affect the affairs of this one could lie behind some of the appeal of the LBS. So could Jenkins's utilitarian style which depicts the apocalypse in the narrative analogue to plain brown paper, with occasional hints of the confessional prosody of Edward Taylor and the confrontational one of Jonathan Edwards. At the end of the day, it may have been a selling point with the consumers: a book that tells it plainly like it is. 
19 True enough, ignoring most cardinal rules of narration, LaHaye and Jenkins tell it all. They tell us that Buck is a writer's writer, although they never furnish a word of his scintillating prose. They tell us that Carpathia's oration to the UN General Assembly brims with incredible knowledge, but the two paragraphs of it we get to see are banality itself (243). Nonstop editorializing, such as when they tell us that the Antichrist rose from his chair with "pseudodignity" (447) is on a par with third-grade theology, such as when Steele undergoes an epiphany: "if genesis meant 'beginning', maybe revelation had something to do with the end" (121).

Isaac Asimov's often quoted (and not unsympathetic) quip that the Golden Age of science fiction is twelve also holds for premillennialist fiction. It is more than the matter of the faithful walking unscathed through A-bomb blasts or of lions becoming petting-zoo leaf-eaters. In what passes for the debate on abortion in Left Behind, the only pro-choice argument comes from Hattie, the whore of Babylon: abortions are good or abortion clinics could not make a living (267). "Heckuva" is the limit of adult language in the White House, perhaps in deliberate contrast to the Nixon tapes which shocked Americans as much with their dirty tricks as with four-letter expletives. But not to worry. In the tradition of Christian romances or holy rock music, Satan's henchmen will condemn billions to nuclear hell but will not say "hell" in the middle of the most heinous acts.

21 Torn between evangelizing and selling copy, LaHaye and Jenkins settle for an uneasy truce, with dispensationalist exhortations scrambled palimpsest-like into an action thriller. This helps explain why, when they profess that during the Rapture "everything was left behind" (16), they do not stop to sort out the theological import of grafted skin, artificial limbs, transfusion plasma, and other miracles of modern medicine that should have also been left behind. The apocalyptic plotline has no room for such trifles, so long as Left Behind XVI is gorier than Left Behind XV. On cue, battle forces in Kingdom Come (2007) are a millennial thousand times larger than in Glorious Appearing (2004).

22 In narrative terms, the LBS is a franchise made in heaven, with sequels built-in by the premise of prefiguration. After all, the last sentence of Left Behind could well be the first sentence of the sequel, Tribulation Force: The Continuing Drama of Those Left Behind: "The task of the Tribulation Force was clear and their goals nothing less than to stand and fight the enemies of God during the seven most chaotic years the planet would ever see" (468). To be continued. By their own admission, LaHaye and Jenkins were taken aback by the popularity of what was first a trilogy, written in the hope of reaching half a million readers, which morphed into a bestselling dodecalogue and finally a sixteennovel franchise with a long line of merchandise. Upsizing the narrative canvas, and consequently recycling subplots and second-string characters, has unintended comic effects, such as when one infiltrator of the Antichrist's computer banks falls by the wayside, only to be replaced by his narrative clone, different in name but little else.

23 The Tribulation Force is LaHaye and Jenkins's evangetainment hybrid of born-again Green Berets and "Doomsday Preppers" from the National Geographic channel realityTV series. As befits an evangelical comic book, albeit one without frames, Christ's commandos are top-gun graduates of the lantern-jawed school of Dick Tracy vintage. Jesus Christ himself is little more than the quintessential deus ex machina. Alighting over the fields of Armageddon, he smites his enemies and blesses the dispensationalist creed in pages upon pages of rambling monologue excerpted verbatim from the 
Scriptures. What should have been the series' most exalted sequence, evincing the true measure of its epic design, is nothing short of an epic anticlimax.

No less questionably, LaHaye and Jenkin replace the charitable turn-the-other-cheek Essene from the Gospels of Matthew and Luke with a death-sowing theocrat. The premillennial Savior in all but name mimics the Antichrist. Carrying himself with vanity, stamping out all theological opposition, the dispensationalist Messiah tolerates only faith that is not even blind so much as servile. In the dispensationalist disjunction tertium non datur: either you're with us or you're against us. Even more incongruously, in The Rising (2005) young Carpathia encounters an unidentified character who leads him to a desolate wasteland, forsakes him for forty days, bids him turn stones into bread and to throw himself off a temple roof and be saved, and pledges to him all the kingdoms of the world "if you but kneel down and worship me" (379)-all in an outré recreation of the temptations of Christ. This incongruity carries even into the spinoffs, such as the violent Left Behind: Eternal Forces video game, in which players can hack away at Christians as troopers of the Horned One.

25 Even as the LBS pays homage to the wisdom of every man and woman reading the Bible for him- or herself, the only interpretation that looms self-evident to everyone is LaHaye's. ${ }^{\text {ix }}$ Not one word about those who read the Bible differently, as all unbelievers and most believers do. Not one word about its prophecies being as lucid as those of Nostradamus. Not one word about the standard problems of textual scholarship rooted in the fact that the Scriptures collate fragmentary and often contradictory accounts written by chroniclers with vested religious and sociopolitical agendas.

26 All of which highlights the fundamental quandary of appealing to the Bible as the ultimate religious or political authority: Which is the biblical text? Is it the synoptic gospels? And if so, in which transcription: Aramaic, Coptic, Koine Greek, or Latin-and why? Or is it some synthetic reconstruction thereof? If so, does it include the apocrypha (and whose apocrypha)? The Dead Sea scrolls? The Nag Hammadi codices? The Codex Tchacos, including the recently discovered Gospel of Judas? If LaHaye is even aware of these and other hermeneutical conundrums, he dismisses them out of hand. ${ }^{\mathrm{x}}$

27 Were the LBS Paradise Lost, its most interesting creation would be the ur-rebel with a cause: the Romanian-born Antichrist. And so he is, in the first half of Left Behind, before he plays his hand and becomes a cipher onto which LaHaye and Jenkins write all their religious and political evils. The name of the Beast is a portmanteau of Nicolae Ceausescu, the communist-era despot of Romania notorious for his personality cult, and the Carpathian range of Transylvania, home to the infamous Vlad Dracula.

28 In political terms, the Antichrist heads the organization that, in the eyes of LaHaye and his fellow dispensationalists, aims to emasculate the United States. Symbolically, the great deceiver, who is fluent in all six of the official UN languages, removes its headquarters from New York to Babylon. Just like his social platform which brims with the global-village rhetoric straight from the mouths of American liberals, his campaigns to end Third World hunger, unify global currencies, and foster ecumenical coexistence of the world's religions prove to be satanic ruses. But it is Carpathia's call for global disarmament that marks him for what he is. Given that the Tribulation is said to be unavoidable, anyone who brings peace must be a false pretender, if not the devil incarnate. with "millenarianism, eschatology, the Last Judgment, and the second coming of 
Christ" (255), a rather different agenda from that of most members of Congress. Still, when the Tribulation Force is pressed to keep an eye on him, LaHaye's message could not be more plain: born-again Christians should keep an eye on American politics and politicians. His fiction reincarnates his nonfiction: throughout his career LaHaye has made it no secret that "leadership in America should be filled by Christian men and women” (Bible's Influence 83).

\section{De Gustibus Non Est Disputandum}

Historically, even as the obsession with the end of the world peaks with every fin de siècle, it reaches maximum intensity at the end of every millennium, much as it did during the Dark Ages when the entire Christendom quailed in terror on the eve of 1 January, 1000 A.D. Never mind that the medieval theophanists failed to get their Judgment Day right, what with calendar reforms from Numa Pompilius onward or the absence of zero in the Roman numerical system.

31 Proving that modern minds are no less susceptible to eschatological superstition, in 1809 the Reverend George Stanley Faber published A General and Connected View of the Prophecies Relative to the Conversion, Restoration, Union, and Future Glory of the Houses of Judah and Israel; the Progress, and Final Overthrow, of the AntiChristian Confederacy in the Land of Palestine; and the Ultimate General Diffusion of Christianity. With the help of numerology and other techniques, he divined that the Antichrist was Napoleon Bonaparte and that the world would end with the end of the latter's imperial rule.

32 Over the next two centuries, undeterred by the predictive successes of Faber and his league of successors, countdowns to Armageddon began to multiply at an accelerating rate, once more rising to a crescendo as the second millennium drew to a close. Increasingly, however, cognizant that they were swimming against the tide of modern science, apocalyptic prophets would preemptively voice their disdain for critical reasoning. Like LaHaye and Jenkins, time and time again they would exhort readers "to move beyond being a critic, an analyst" (214). Without batting an eyelid, on the other hand, they would appeal to reason in their divinations, as Edgar C. Whisenant did in 88 Reasons Why the Rapture Is in 1988 (1988).

33 Reason dictates, of course, that, quite apart from their continuously revised timetables, the very proliferation of apocalyptic prophecies reduces their credibility to zero. But even as it pays lip service to reason, dogma is immune to it. It is for no other reason that, armed with convoluted charts, Marylin J. Agee could announce in The End of the Age (1994) that the End Times were due on 31 May, 1998, and when things did not quite work out that way, calmly sit down to write Revelations 2000 (1998).

34 In Planet Earth-2000 A.D. (1994), Hal Lindsey counselled all Christians not to plan to be on planet Earth by the year 2000. This was the same Lindsey who back in 1970 predicted Armageddon for the 1980s in the bestselling nonfiction of the decade, The Late Great Planet Earth (ghost-written by Carole C. Carlson). In between, Lester Sumrall waved goodbye to Earth in I Predict 2000 A.D. (1987), Charles Berlitz and J. Manson Valentine obliterated it in Doomsday 1999 A.D. (1981), Kirk Nelson prophesied the Second Coming in The Second Coming 1998 (1998), Harold Camping foretold the end of the world for 1994 in 1994? (1992), then for 2011 in Time Has an End: A Biblical History of the World 11,013 BC$2011 A D$ (2005), and so on. 
35 Pinpointing the end of the world is even more popular in fiction which allows authors to reach a wider audience without losing credibility over falsifiable prophecies. Dispensationalist fiction, it must be said, is distinguishable from nonfiction primarily because in the latter, the authors incestuously cite one another as evidence of scholastic respectability. Paradoxically, the same evangelists who profess their disdain for critical thinking never fail to shore up their eschatology with exegetical "proofs" cited thereafter in the stream of "scholarly" publications as evidence of their accuracy. In recent years, the line between premillennialist fiction and nonfiction has blurred even further owing to the burgeoning practice of releasing novels in parallel with ancillary pseudo-scholarly apparatus. In study guides, digests, and workbooks such as The Authorized Left Behind Handbook (2005), dispensationalists neglect no opportunity to spell out their nonfictional exegeses of their fictional exegeses of the Bible.

36 But it was The Late Great Planet Earth and its triumph at the box-office that spawned a whole school of "have Scofield Bible, will novelize." Lindsey himself was nearly beaten to the punch by Joe Musser -later a co-author of a long line of thrillers with Irangate Oliver North-and the apocalyptic Behold a Pale Horse (1970). Also in 1970 appeared 666 by the founder of the Second Coming Ministries, Salem Kirban. Three years later it was followed by his premillennial sequel, titled simply 1000. Kirban's associate, Gary Cohen, rolled out his version of the Armageddon in Civilization's Last Hurrah (1974). He was followed by Frank Allnutt of New Heart Ministries whose The Peacemaker (1978) featured a Henry Kissinger look-alike as the Antichrist.

37 In 1979 Carol Balizet of Home in Zion Ministries released The Seven Last Years. Pastor Dan Betzer of First Assembly of God finished the Earth off in The Beast: A Novel of the Coming World Dictator (1985). Frank Peretti, assistant pastor with the Assemblies of God, followed suit with This Present Darkness (1986) and Piercing the Darkness (1989), in which, among other evils, demon-seized professors corrupt university curricula and students. Erstwhile professor of politics and NSA analyst, James BeauSeigneur, contributed Christ Clone Trilogy, to this day the most literary specimen of the dispensationalist genre (republished by Warner in 2003-2004).

38 He was followed by evangelist and part-time exorcist Bob Larson with Abaddon (1993), himself followed by evangelist and candidate for President of the United States Pat Robertson with The End of an Age (1995), himself followed by a former Moody radio affiliate David Dolan with The End of Days (1997), followed by Peter and Paul Lalonde's Apocalypse (1998), followed by Mel Odom's Apocalypse Dawn (2003), and so on in a long and growing line of paper apocalypses. ${ }^{\mathrm{x}}$

39 Subject to the same commodifying pressures as other pulp genres, dispensationalist fiction recycles similar plotlines, basing them on the premise that the history and the calamitous future of our civilization are described in the scriptures. At the same time, through the process known in ecology as adaptive radiation, it produces an endless number of variations on this basic template. With the lion's share of every novel devoted to the terrors visited upon the Earth first by God and then by Satan, the sevenyear Tribulation looks every inch like the seven-year itch that has to be scratched over and over again-albeit to no avail, since the compulsion to foretell the day when the Antichrist rides into Babylon on a pale mount shows no signs of tapering off.

40 Facing these anachronistic prophecies, a skeptical inquirer may be excused for asking where fiction ends and reality begins. The standard concept of "reality" does not, of course, allow for much in-betweenness. Its semantic bivalence is simple: something is 
either real like a pen, or unreal like a unicorn. But what about the reality of centers of gravity? You can never hold the latter in your hand like you hold a pen, yet civil engineers and acrobats stake their lives on them. Interestingly, psychoanalytic talkcures or psychosomatic placebos work to the extent people believe them to be real.

41 On 1 July, 2002 a Time/CNN poll reported that nearly sixty percent of Americans believe that the apocalyptic prophecies intimated in the Book of Revelation will come to pass. ${ }^{\text {xii }}$ No matter that this belief flies in the face of scientific knowledge, not to mention the Bible itself which appears to put the End Times at the end of the first century A.D. (Matthew 24:34). No matter that we have by now survived hundreds of these premillennial and postmillennial apocalypses, always to wake up the morning after and go to work.

42 Any rational enterprise that got all of its deductions and predictions wrong might be tempted to take a step back and re-assess the theory on which they are based-in this case the theory of Rapture, Tribulation, and Apocalypse. But not premillennialism. The rapture, insist LaHaye and Jenkins, "could not be dissected and evaluated scientifically from a detached Ivy League perspective" (394), demanding a suspension of disbelief instead. At the end of the day, much like in art, in religion de gustibus non disputandum. All the same, as a literary critic with a mandate to think critically, I prefer to throw my lot in with Paul Tillich who, in his existential sermons collected in The Shaking of the Foundations, warned that the command "to sacrifice one's intellect is more demonic than divine. For a man ceases to be man if he ceases to be an intellect" (62).

\section{Apocalypse Now}

43 For American Christianity these may be the worst of times and the best of times. Many congregations are in decline, sex and child-abuse scandals are driving even lifelong pew sitters away, and in some areas of life, from gene therapy and contraception to abortion and gay marriage, the church looks look antiquated, perhaps even reactionary. Not much seems to have changed, in short, from 1966 when Time magazine baited Americans from its first-ever pictureless cover with: "Is God Dead?"

44 Naturally, rumors of God's demise have been greatly exaggerated. In April 2005, for example, Marie Claire ran a feature on Christian iconography which left little doubt that the divine brand identification could be the envy of every marketing whiz. Crosses are ubiquitous, it reported, splashed on billboards, dangling from necks and ears, tattooed on raw skin. God speaks from t-shirts, bumper stickers, and coffee mugs. Jesus sells a diversified portfolio of products, from diets (kosher) to hobbies (carpentry) to footwear (sandals). This is not to even mention a backlist of bestsellers such as What Would Jesus Eat? or, for those who do their penance in the gym, Body By God.

45 In 2007 USA Today published a Gallup poll according to which two out of three American adults believe that the Almighty created human beings in their present form during the last ten thousand years. This dramatic evidence of born-again fervor is even more impressive in light of the fact that, over the last half a century, membership in mainstream denominations has nosedived. Presbyterian and Methodist congregations, for example, are only half of what they were when Time needled believers from newsstands. The registered numbers of Episcopalians are down by almost sixty percent. Ditto for the United Church of Christ. ${ }^{\text {xiii }}$ 
One can spin these numbers in a number of ways, but there is no denying that bornagain Christianity is no longer playing catch-up to the American religious and cultural mainstream. These days it is part of the mainstream, lending some credence to Pat Robertson and Jerry Falwell's claims of commanding a television audience of one hundred million (Sizer 23, see also Luhrmann). Its religious and political clout, in turn, accounts at least in part for the spike in the numbers and commercial returns of story cycles like Left Behind.

47 Yet, instead of celebrating their social and cultural penetration, many evangelical leaders bemoan society's decline among accusations of moral turpitude and political decay. Neither is this spirit of doomsday anything new. Back during America's bicentennial, Tim LaHaye himself made no bones about the evil rampant in the fifty states. In parallel with his efforts to counter the work of the American Civil Liberties Union, the National Organization for Women, and the National Association for Education, he thundered under the imprint of Christian Heritage College: "Today we face our greatest enemy, atheistic humanism, which seeks to destroy our moral character and divert us from the principles that have produced the greatest nation in the history of the world" (LaHaye, Bible's Influence 33).

48 Forget global warming, with the fate of the planet hanging in the balance. Forget the menace of militant fundamentalism at home and abroad. Forget street violence, drug culture, systemic poverty, political disfranchisement, and education limping on a wing and a prayer. None of them pose as much threat as America's Enemy Number One: humanists who have wrested the helm of the ship of state from the hands of born-again Christians. And the results of their machinations? Nothing short of Apocalypse now:

Government induced socialism in the guise of liberalism is raping the American free enterprise system, human initiative is being sapped by welfarism, the morals of our nation have dropped to an all time low, crime threatens our personal safety, and the liberal media is seeking to control the thinking of our people. (LaHaye, Bible's Influence 73) ${ }^{\text {xiv }}$

49 Oddly, not once does LaHaye and other doomsayers pause to reflect on the fundamental, not to say fundamentalist, self-contradiction in their theologic. On the one hand, they squander no opportunity to affirm that the Almighty is in absolute control of everything there is. In Left Behind LaHaye and Jenkins could not be more categorical that all that happens happens as decreed by a celestial master plan: "Bible prophecy is history written in advance" (214). They reprise their message in The Remnant: "God has given us in the Bible an accurate history of the world... It is the only truly accurate history ever written" (228). The belief in predestination goes so far that Tsion Ben Judah, the authors' ill-concealed mouthpiece, enunciates in Soul Harvest: "the outcome has already been determined. We win!" $(247)^{\mathrm{xv}}$

50 This is why, taken at face value, evangelical fulminations against atheism, humanism, liberalism, socialism, or other "isms" could be considered inherently blasphemous. If history unfolds in accordance with what is in the Bible, twentieth-century liberalism and humanism are also agents of the divine will. Opposing them amounts to opposing God's decree which is not only sacrilegious but, in fundamentalist terms, impossible. In sum, LaHaye advocates rebellion against divine providence while maintaining that it cannot be done-a logical and theological suicide.

51 Undoubtedly, a devil's advocate might object at this point that this entire reductioad absurdum is predicated on taking Left Behind and its exegetical maneuvers at face value. 
Is it not, however, a category error to read fiction as if it wasn't? Is it not wrongheaded to emulate Madame Bovary and take LaHaye's novels to be the gospel truth? Has not Sir Philip Sidney already apologized on behalf of every writer that he nothing affirmeth, and therefore never lieth? He has, while holding his fingers crossed behind his back. As Sidney knew too well, literary fiction can have profound consequences in the real world. Even those novels that do not make national history like Uncle Tom's Cabin or The Jungle did, remake readers in their image by affirming or challenging their ideas about the world. But it is when they expressly call on readers to stand up for these ideas that they expressly cross from fiction into political activism and mass propaganda.

52 Such is the case when LaHaye and Jenkins demonize their partisan adversary, Molly Ivins, known for her libertarian broadsides at born-again Republicans from Pat Buchanan to George W. Bush. In the Left Behind series she is incarnated as Viv Ivins, a woman who raises the Antichrist and whose very name in Roman numerals spells VI VI VI-the number of the Beast. Importing their fundamentalist and Republican commitments so expressly into their fiction, LaHaye and Jenkins deliberately renounce Sir Philip Sidney's defense. In the end, the Left Behind novels more than license being read in the light of their authors' real-life religious and partisan convictions. They demand it, precisely because they represent a mass-market popularization of their apocalyptic eschatology and their arch-conservative politics.

\section{Dehistoricizing History}

53 One should not judge a book by its cover, but in the case of Left Behind the original hardcover from Tyndale House corroborates The New York Times' dismissal of the LBS as a literary "exercise in brand management" (Kristof A23). Bible-black monochrome with a stenciled title serves as an emblem of the Good Book-and, as such, a good book. Between the covers, unjustified margins reinforce the symbolism. No justification is needed in a book premised on transcribing God's moves for the Endgame. No matter that Matthew 24:34 identifies End Times with the end of the first century A.D., leaving its modern exponents behind by nearly two thousand years.

54 In a tacit admission of this flagrant anachronism, in the preface to the final book in the series LaHaye forswears his core premise of reading the Bible literally. In a dramatic uturn, God is now to be taken at His word only "wherever possible" (Kingdom Come xiv). In one fell swoop, the purportedly true history of humankind is reduced to a hermeneutist's paradise. The problem is, of course, that there is little in the old Testament to justify LaHaye's hermeneutics in the name of the New. The alleged prophecies of the Second Coming of Christ in our time are taken out of context and hammered onto gospels that by and large have little to say about them.

55 The real guiding light in all such free-for-all exegeses, documents James Barr in Fundamentalism, is not the gospel truth but the impulse to show the Bible to be inerrant. Cherry-picking the scriptures for "evidence," often by means of free association and wordplay, premillennialists forsake "the literal sense as soon as it would be an embarrassment" (46). ${ }^{\text {xi }}$ Worse, LaHaye's gospel à la carte is grounded in conspicuous misinterpretations. It is more than the awkward fact that there is not one word in the Scriptures about dispensations, and even less about the Rapture or the Tribulation. In Tribulation Force and then in Soul Harvest LaHaye and Jenkins claim that the Tribulation 
Force is named after "what the Bible calls "tribulation saints"' (236). Except the phrase "tribulation saints" is absent from the Scriptures.

56 At the end of the day, all this narrative and theological skullduggery makes it difficult to see the LBS as anything else but a species of juvenile adventure. Whatever its artistic and aesthetic demerits, on the other hand, it has more than proven its staying power with American readers (tellingly, translations were almost uniformly flops). So what that, as weapons in the fight for the minds of the American public, the Left Behind novels are artless and crude? Much as in politics, in religion a bludgeon is sometimes more effective than a lancet.

57 Moreover, even if forgettable as an aesthetic experience, the LBS is invaluable as a social seismograph for getting a reading of the influence of Christian fundamentalism in American public life. This is largely because apocalyptic fiction never strays far from politics tout court. As a matter of fact, many tenets of evangelical Christianity, such as the absolutist view of the scriptures, the belief in divine agency, or the desegregation of state and religion are mirrored in its political platform-such as an apocalyptic view of history, the displacement of democracy by charismatic leadership, and the advocacy of behavioral control. xvii

58 The end results of the apocalyptic notion of history are particularly insidious. The Judgment Day perspective on the course of human affairs in effect dehistoricizes world history, replacing self-realization and material causation with the divine finger in the name of a teleological fulfillment of wildly anachronistic divinations. More perniciously still, it transmutes the workaday political process-premised as it is on vigorous debate, hardnosed negotiations, and bipartisan horse-trading-into an apocalyptic standoff between the forces of good and evil.

59 Apocalyptic politics in the United States goes beyond evocations of doomsday, branding of sundry axes of evil, appeals to "What Would Jesus Do?" or agitprop about America's divine election. Crucially, it eliminates the political middle ground and the presumption of vectoring a collective impulse, and with them the culture of collaboration and compromise. In their place it cultivates a politics of hardline disjunctions, block refusals, and wedge issues contrived to polarize the electorate and turn partisan politics into a zero-sum showdown of Manichean proportions. In short, to borrow a word from Jon Stewart, it turns American politics into a daily cliffpocalypsemageddonacaust.

60 Seen in this light, apocalyptic fiction and apocalyptic evangelism are clearly not just about religion. Krishna Kumar's analysis of modern-era fundamentalism in India is particularly useful in this context. His insights into communalism-whereby a community of adherents shares not only religious affiliation but also social, economic, and not least political objectives-open a window onto the engagé variety of fundamentalism ascendant nowadays in the United States. Personified by the authors of Left Behind, it stands in sharp contrast to the traditional Christian suspicion of striving for reward in this world as opposed to the next.

61 Like all other fundamentalist denominations, dispensationalism has traditionally viewed human history as inherently corrupt, with the contemporary times as the best case in point. Such a perspective is not conducive to active engagement in society's affairs, seen as they are as a source of degeneracy and vice. Indeed, the dimensions of the political revolution in evangelical circles is apparent when one considers that in the 
first half of the twentieth century several denominations questioned whether it was even moral to vote. .viii

62 The apparent clash with science, reason, and liberal social values has led many to see in fundamentalism a rejection of modernity and even an epitome of antimodernity. ${ }^{\text {xix }}$ It is at least as plausible, however, to see it as a quintessential expression of modernity and its fragmented, unstable nature that produces a cultural antithesis for every thesis. Ironically, with dispensationalism ambivalent about so much of the contemporary world, dispensationalist fiction exploits this anxiety even as it recruits rank and file for its political goals.

63 Today millennialism and meliorism go hand in hand with an active, even proactive, attitude to social engineering and political engagement. Historian Michael Standaert makes this point in the context of LaHaye and the LBS by showing how the grafting of dispensationalist theology on the American myths of exceptionalism and rightwing conspiracy fantasies made for resurgent political activism (27). Johann Pautz describes how Left Behind belongs to a far-right social landscape that runs from the Militia Movement to the John Birch Society, exerting "considerable influence in American politics" (283). And Melani McAlister completes the picture of evangelism engagé by detailing how evangelical fiction and nonfiction articulate a clear and present "political agenda" (775).

\section{Coda: Judgment Day}

64 Historically, the granddaddy of apocalyptic bestsellers was not Left Behind or The Late Great Planet Earth but Michael Wigglesworth's 1662 narrative poem The Day of Doom. His literary terrors of Judgment Day, especially the part in which God damns unbaptized children to hell, proved so scandalizing to its contemporaries that today not one copy of the first two editions survives. They were all thumbed to shreds.

65 Viewed in one light, the LBS is no more than a commercial spinoff from the bestselling and arguably most important book in the history of the Western civilization. Viewed in another, however, it is an embodiment of a time-honored tradition of modernizing the Christian gospel for its contemporaries. Going back to the ancient corpus of Vetus Latina, via the now canonical Vulgate, it extends right up to the beehive of twenty-first century Bibles tailored to the eclectic tastes of American consumers.

66 For the tree-huggers there is the Green Bible printed on recycled paper with soy ink, with all references to the environment highlighted in green. For the yuppies there is the Bible Illuminated in a GQ-style glossy oversized format and adorned by photos of celebrities from Che Guevara to Angelina Jolie. There is the Power of a Praying Woman's Bible, Spiritual Warfare Bible, Spirit-filled Life Bible, Livin' Out Your Faith Bible, Duct Tape Bible, Backpack Bible, Extreme Teen Bible, American Patriot Bible, and -rounding up a catalogue of hundreds of other niche offerings-the Veggie Tales Bible.

The evangelical United States may not be ready, however, for the findings documented in 2009 in Evolutionary Psychology. Countries with low levels of social dysfunction-as measured by the rates of homelessness, unemployment, teen pregnancies, abortion, divorce, imprisonment, homicide, STDs, and others-are invariably the most secular. In contrast, countries afflicted by social problems, such as the United States, are the most religious (as reflected by belief in God, religious service attendance, frequency of 
prayer, and so on). Behind the correlation lies causality. The easing of social and economic problems dims religiosity, while social ills turn it back on. ${ }^{\mathrm{xx}}$

The apparent ease with which populations shrug off God when conditions improve bucks the view popular in American evangelical and political circles that religious observance is the bedrock of existence. Instead, it appears to be an adaptable coping mechanism. When socioeconomic dysfunction reaches critical levels, people deal with the trauma by turning their eyes toward heavens. This is an awkward truth in a country in which, if Tim LaHaye and Jerry B. Jenkins are anything to go by, "atheist" and "humanist" are four-letter words. A country in which coordinated political action from groups such as the Moral Majority and Christian Coalition of America aims to keep godless liberals from forging a nation in their own image. A country whose elected representatives apparently aim to convert it into a theocracy, with the Bible in the place of the Constitution.

The rallying cry of the religious right is, after all, that the Constitution was written to promote a Christian order. So what that this contradicts the historical record? "If you're not electing Christians, then in essence you're going to legislate sin," holds Florida Congresswoman Katherine Harris, co-chair of Bush II's 2000 election campaign and a would-be Senator. ${ }^{\text {xxi }}$ Some Senators even vow not to confirm atheists to the Supreme Court, thus violating the very Constitution-which mandates that no religious test shall ever be required as a qualification to any office or public trust-on which they took an oath. .xii $^{\text {. }}$

\section{BIBLIOGRAPHY}

Barr, James. Fundamentalism. Philadelphia: Westminster, 1977. Print.

Bergen, Wesley J. "The New Apocalyptic: Modern American Apocalyptic Fiction and its Ancient and Modern Cousins." Journal of Religion and Popular Culture 20:3 (2008). Print.

Bernstein, Michael A. Foregone Conclusions: Against Apocalyptic History. Berkeley: University of California Press, 1994. Print.

Chafets, Zev. “The Huckabee Factor.” New York Times Magazine. 12 December (2007). Web. Accessed 15 June, 2014.

Chapman, Jennie. “Tender Warriors: Muscular Christians, Promise Keepers, and the Crisis of Masculinity in Left Behind." Journal of Religion and Popular Culture 21:3 (2009). Web. Accessed 15 June, 2014

Dershowitz, Alan. Blasphemy: How the Religious Right Is Hijacking Our Declaration of Independence. Hoboken, NJ: John Wiley and Sons, 2007. Print.

Dreyfuss, Robert. "Reverend Doomsday: According to Tim LaHaye, the Apocalypse Is Now." Rolling Stone Jan. 28 (2004): 35-38. Print.

Freddoso, David. "Who Would Confirm an Atheist to the Supreme Court?" 58:26 Human Events, 15 July (2002): 3. Print. 
Faber, George Stanley. A General and Connected View of the Prophecies Relative to the Conversion, Restoration, Union, and Future Glory of the Houses of Judah and Israel; the Progress, and Final Overthrow, of the AntiChristian Confederacy in the Land of Palestine; and the Ultimate General Diffusion of Christianity. Boston: William Andrews, T. B. Wait, and Co. https://archive.org/details/ generalconnectedoofabe. Web. Accessed 30 July, 2014.

Frey, Rebecca Joyce. Fundamentalism (Global Issues). New York: Facts on File, 2007. Print.

Gold, Malcolm. "The Left Behind Series as Sacred Text?" Reading Religion in Text and Context: Reflections of Faith and Practice in Religious Materials. Eds. Elizabeth Arweck and Peter Collins. Hampshire, UK: Ashgate, 2006. 34-49. Print.

Gribben, Crawford. “After Left Behind-The Paradox of Evangelical Pessimism." Expecting the End: Millennialism in Social and Historical Context. Eds. Kenneth G. C. Newport and Crawford Gribben. Waco, TX: Baylor University Press, 2006. 113-130. Print.

---. Prophecy Fiction in Evangelical America. Oxford: Oxford University Press, 2009. Print.

Guyatt, Nicholas. Have a Nice Doomsday: Why Millions of Americans Are Looking Forward to the End of the World. London: Ebury, 2007. Print.

Kasser, Rodolphe, Marvin Meyer, and Gregor Wurst, eds. The Gospel of Judas: from Codex Tchacos. Washington, D.C.: National Geographic, 2006. Print.

Kramnick, Isaac and R. Laurence Moore. The Godless Constitution: The Case against Religious Correctness. New York: Norton, 1991. Print.

Kristof, Nicholas D. “Apocalypse (Almost) Now.” New York Times 24 November (2004): A23. Print. Kumar, Krishna. “Religious Fundamentalism in India and Beyond.” Parameters 32:3 (2002): 17-34.

LaHaye, Tim. The Bible's Influence on American History. San Diego: Christian Heritage College, MasterBooks. 1976. Print.

LaHaye, Tim, and Jerry B. Jenkins. Left Behind: A Novel of the Earth's Last Days. Wheaton, IL: Tyndale House, 1995. Print.

---. Tribulation Force: The Continuing Drama of Those Left Behind. Wheaton, IL: Tyndale House, 1996. Print.

---. Are We Living in the End Times? Current Events Foretold in Scripture and What They Mean. Nashville, Tenn.: Tyndale House, 1999. Print.

---. Soul Harvest: The World Takes Sides. Wheaton, IL: Tyndale House, 1999. Print.

---. The Remnant: On the Brink of Armageddon. Wheaton, IL: Tyndale House, 2002. Print.

---. Glorious Appearing: The End of Days. Wheaton, IL: Tyndale House, 2004. Print.

---. Kingdom Come: The Final Victory. Wheaton, IL: Tyndale House, 2007. Print.

Luhrmann, T.M. When God Talks Back: Understanding the American Evangelical Relationship with God. New York: Knopf, 2012. Print.

Lindsey, Hal, with Carole C. Carlson. The Late Planet Earth. Grand Rapids, MI: Zondervan, 1970. Print.

Mathewson, Dan. "End Times Entertainment: The Left Behind Series, Evangelicals, and Death Pornography." Journal of Contemporary Religion 24:3 (2009): 319-337. Print.

McAlister, Melani. "Prophecy, Politics, and the Popular: The Left Behind Series and Christian Fundamentalism's New World Order." South Atlantic Quarterly 102:4 (2003): 773-797. Print. 
Metzger, Bruce M. The Text of the New Testament: Its Transmission, Corruption, and Restoration. $3^{\text {rd }}$ ed. New York: Oxford University Press, 1992. Print.

Morrison, Richard. “Armageddon Ahead: Please Fasten Your Bible Belt.” The Times 20 September (2002): T2, 2-3. Print.

Paul, Gregory. "The Chronic Dependence of Popular Religiosity upon Dysfunctional Social Conditions." Evolutionary Psychology 7:3 (2009): 398-441. Print.

Pautz, Johann. "The End Times Narratives of the American Far-Right." In Kinane, Karolyn and Michael A. Ryan, eds. End of Days: Essays on the Apocalypse from Antiquity to Modernity. Jefferson, North Carolina: McFarland and Company, 2009. 265-286. Print.

Price, Robert M. The Paperback Apocalypse: How the Christian Church Was Left Behind. Amherst, NY: Prometheus, 2007. Print.

Scofield, Cyrus Ingerson. The Old Scofield Study Bible: King James Version, Standard Edition. Oxford: Oxford University Press, 1999. Print.

Shuck, Glenn W. Marks of the Beast: The Left Behind Novels and the Struggle for Evangelical Identity. New York: New York University Press, 2005. Print.

Sizer, Stephen R. Christian Zionism: Road-map to Armageddon? Leicester, UK: IVP, 2004. Print. Standaert, Michael. Skipping Towards Armageddon: The Politics and Propaganda of the Left Behind Novels and the LaHaye Empire. Brooklyn, New York: Soft Skull, 2006. Print.

Sutherland, John. "Apocalypse Now." Rev. of Armageddon: The Cosmic Battle of the Ages by Tim LaHaye and Jerry Jenkins. The Guardian 12 June 2003. Web. Accessed 15 June, 2014.

Swirski, Peter. American Utopia and Social Engineering in Literature, Social Thought, and Political History. New York, London: Routledge, 2011. Print.

Tillich, Paul. The Shaking of the Foundations. New York: Scribner's, 1948. Print.

Demographia. "Trends in Large U.S. Church Membership from 1960.” Web. Accessed June 15, 2014.

Wacker, Grant. Heaven Below. Cambridge, MA: Harvard University Press, 2001. Print.

Weremchuk, Max S. John Nelson Darby: a Biography. Neptune, NJ: Loizeaux Brothers, 1993. Print.

Whisenant, Edgar C. 88 Reasons Why the Rapture Will Be in 1988. Nashville, TN: Whisenant/World Bible Society, 1988. Print.

Wigglesworth, Michael. The Day of Doom, or a Poetical Description of the Great and Last Judgment: With Other Poems. London: Forgotten Books, 2012. (Orig. 1662.)

Wilkinson, Paul. For Zion's Sake: Christian Zionism and the Role of John Nelson Darby. Milton Keynes, UK: Paternoster, 2007. Print.

\section{NOTES}

i. For the dimensions of LaHaye's educational and political empire, see Standaert.

ii. On Kemp campaign, see Dreyfuss; Huckabee quote in Chafets.

iii. On Darby, see Sizer; Wilkinson; Weremchuk.

iv. On Darby's textual exegeses, see Frey; Shuck.

v. Shuck, 37. 
vi. Co-written with John Castle.

vii. Buck Williams may be based on Tom Hammond, bachelor journalist hero of the earlytwentieth-century premillennialist novels of Sydney Watson.

viii. All subsequent references are to Left Behind unless indicated otherwise.

ix. This point is elaborated by just about every ecclesiastical commentator on the series, including Price; Bergen; Mathewson; Chapman.

x. On biblical transmissions, corruptions, and restorations, see Metzger; the Gospel of Judas in Kasser, Meyer, and Wurst.

xi. For plot précis, see Price; Shuck; Gribben (2009, Chapter 7) tracks other prophecy fictions after the LBS.

xii. See Sutherland.

xiii. See Demographia.

xiv. For background see Guyatt, esp. 245-277.

xv. For background see Bernstein.

xvi. See also Gold, 40; below, Price, 294.

xvii. Frey, especially Introduction; in Marks of the Beast, Shuck deliberately separates the two terms (and favours the first); for behavioural engineering and charismatic leadership, see Swirski (2011).

xviii. Wacker, Chapter 13.

xix. Gribben (2009).

xx. Paul; Luhrmann re-articulates the coping mechanism thesis on page 320.

xxi. Kramnick and Moore, 22; Harris in Dershowitz, 117.

xxii. For the US Senators James Inhofe (R-Oklahoma) and Don Nickles (R-Oklahoma), see Freddoso.

\section{ABSTRACTS}

The article focuses on the cultural and political implication of the recent publishing sensation from two fundamentalist Christian ministers-turned-writers: Tim LaHaye and Jerry B. Jenkins. Their sixteen-book Left Behind Series (1995-2007) has by now sold close to eighty million copies, crossing over from the evangelical margins to the bookseller's mainstream. Focusing by and large on the first novel in the series, the article analyzes its narrative and political logic in the context of the rise of apocalyptic imagery in American culture and public life.

INDEX

Keywords: Left Behind; Tim LaHaye; Jerry B. Jenkins; apocalypse; American literature; American politics. 
AUTHOR

PETER SWIRSKI

Sun Yat-sen University 